\title{
Care este natura juridică a decretelor Președintelui României emise pentru instituirea și prelungirea stării de urgență?
}

Rezumat: În acest articol voi examina natura legală a decretelor Președintelui pentru instituirea și prelungirea stării de urgență. În ciuda conținutului care prevede multiple restricții ale execițiului unor drepturi și libertăți fundamentale, în fapt, aceste decrete rămân adevărate acte administrative normative emise în vederea punerii în aplicare a prevederilor Ordonanței de Urgență nr. 1/1999 privind regimul stării de asediu și regimul stării de urgență, așa cum a fost aprobată prin legea organică a Parlamentului nr. 453/2004.

Cuvinte cheie: stare de urgență, decret prezidențial, natura juridică, acte administrative

\section{Which Is the Legal Nature of the Romanian President's Decrees Issued in order to Institute and Prolong the State of Emergency?}

Abstract: In this article, I shall examine the legal nature of presidential decrees for instituting and prolonging the state of emergency. Despite their content, which provides various restrictions on fundamental rights and liberties, in fact, they remain true normative administrative acts issued in order to execute legal provisions of Emergency Ordinance no. 1/1999 concerning the regime of the state of siege and the regime of the state of emergency, approved by the Parliament through organic law no. 453/2004.

Key words: state of emergency, presidential decree, legal nature, administrative acts

\section{Contextul}

Am scris acest articol în urma a două acțiuni instituționale care s-au desfășurat ieri, 16.04.2020.

Prima este adoptarea de către Parlamentul României a Hotărârii privind încuviințarea prelungirii stării de urgență. În mod cu totul așteptat pentru unii și neașteptat pentru alții, Parlamentul a făcut ceva mai mult decât să încuviințeze prelungirea stării de urgență. A prevăzut, printre altele, cum poate fi restrâns exercițiul drepturilor și libertăților fundamentale în starea de urgență (de ex., numai pe durata stării de urgență, numai pentru motive temeinic justificate și numai prin acte normative cu putere de lege, în temeiul art. 53 din Constituția României). De asemenea, a prevăzut că modificările, abrogările sau completările actelor normative cu caracter legal, 
Lect. univ. dr. Bogdan Dima

Facultatea de Drept, Universitatea din București

Președinte Asociația Centrul pentru Analize Strategice

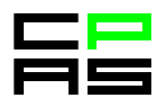

motivate de prevenirea și combaterea pandemiei de COVID-19, se pot dispune numai prin acte normative cu caracter legal.

A doua este sesizarea Curții Constituționale de către Avocatul poporului cu o excepție de neconstituționalitate asupra unor dispoziții din OUG nr. 1/1999. Lăsând la o parte o serie de argumente din această sesizare, care, într-adevăr pot fi relevante, mi-a atras atenția argumentul conform căruia anumite dispoziții din OUG nr. 1/1999 stabilesc pentru Președintele României o competență de legiferare în perioada stării de urgență și, prin urmare, ar fi neconstituționale.

$\mathrm{Nu}$ redactez toate argumentele care pot susține sau combate acțiunile instituționale ale Parlamentului și ale Avocatului poporului. Însă, voi încerca să explic, din punctul meu de vedere, care este natura juridică a decretelor Președintelui, emise în temeiul art. 93 alin. 1 din Constituție și al OUG nr. 1/1999 aprobată prin Legea nr. 453/2004 a Parlamentului.

Dincolo de fricțiunile și luptele politice inerente bietei noastre democrații, mereu în derivă, dacă suntem dispuși să înțelegem natura juridică a decretelor Președintelui în situații excepționale, vom putea înțelege mai bine întreaga arhitectură constituțională și legală care fundamentează regimul juridic al stării de urgență.

Or, dacă înțelegem arhitectura constituțională și legală care fundamentează regimul stării de urgență, putem să înțelegem și faptul că ceea ce a reglementat în plus Parlamentul prin hotărârea de încuviințare a prelungirii stării de urgență intră la categoria stating the obvious (precizează ceea ce oricum era evident și deja reglementat!). De asemenea, va fi mai ușor să înțelegem și faptul că argumentul Avocatului poporului cu privire la neconstituționalitatea dispozițiilor art. 14 lit. $c^{1}$ - f din OUG nr. 1/1999 denotă o confuzie gravă (voită sau nevoită) între competența de legiferare și atribuțiile legale ale unei autorități publice, atribuții care conturează o competență administrativă. Această competență (administrativă) poate fi exercitată în limitele legii sau cu exces de putere, adică prin încălcarea/depășirea scopului legii, caz în care persoanele interesate se pot adresa instanțelor de judecată, instanțe de judecată care, în general, ar fi bine să își realizeze cu entuziasm și competențele, nu doar drepturile.

\section{Opinii cu privire la natura juridică a decretelor Președintelui în situații excepționale}

În literatura de specialitate și în spațiul public se vehiculează trei opinii cu privire la natura juridică a decretelor Președintelui emise în situații excepționale.

Într-o opinie, aceste decrete sunt acte administrative normative, emise în temeiul Constituției și al legii cadru în materie, OUG nr. 1/1999 aprobată prin Legea nr. 453/2004. Astfel, OUG nr. 1/1999 stabilește expres procedura de emitere și ce trebuie să cuprindă decretul Președintelui, inclusiv măsurile de primă urgență care trebuie luate, dar și drepturile și libertățile al căror exercițiu se restrânge, în conformitate cu dispozițiile constituționale și ale ordonanței de urgență. Ca atare, prin conținutul său, decretele Președintelui în situații de urgență sunt acte administrative normative care cuprind măsuri prin care se organizează executarea normelor de rang legal din OUG nr. 1/1999. 
Lect. univ. dr. Bogdan Dima

Facultatea de Drept, Universitatea din București

Președinte Asociația Centrul pentru Analize Strategice

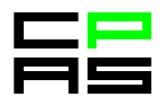

Într-o altă opinie, decretele Președintelui emise în temeiul art. 93 din Constituție sunt acte administrative individuale. Conform acestei opinii, prin aceste decrete doar se instituie sau se prelungește starea de urgență ori starea de asediu. Altfel spus, prin aceste decrete doar se instituie sau se prelungește un regim juridic legal, preexistent. Nu se stabilesc măsuri de punere în executare, de organizare a executării regimului jurdic legal. Mai mult, această opinie consideră că decretele Președintelui pentru instituirea sau prelungirea stării de urgență sau a stării de asediu au rolul de a face incidente Hotărârile CSAT, adoptate în temeiul art. 4 lit. b din Legea nr. 415/2002. Nu este niciun secret faptul că, în temeiul acestor prevederi, la solicitarea Președintelui României, CSAT analizează și propune măsuri pentru instituirea sau prelungirea stării de urgență sau a stării de asediu în întreaga țară ori în unele localități.

Într-o a treia opinie, decretele Președintelui privind instituirea sau prelungirea stării de urgență sunt acte juridice sui generis, care cuprind norme juridice cu forță egală cu a legii, fără a se confunda, însă, cu legea ca act al Parlamentului sau ca act al legiuitorului derivat (Guvernul). Această opinie se întemeiază pe ideea că decretele Președintelui emise în temeiul art. 93 din Constituție și al OUG nr. 1/1999 cuprind dispoziții cu forță juridică egală cu a legii. Cum altfel ar putea califica unii și alții norme juridice care prevăd derogări de la prevederi legale în vigoare sau restrângeri efective ale exercițiului unor drepturi și libertăți fundamentale?

În opinia mea, decretele Președintelui emise în temeiul art. 93 și al OUG nr. 1/1999 sunt acte administrative normative, prin care Președintelui i se cere de către legiuitor să organizeze executarea prevederilor de rang legal din OUG nr. 1/1999. Să vedem și de ce.

\section{Totul începe și se sfârșește cu Legea fundamentală}

Art. 93 alin. 1 din Constituție prevede că Președintele instituie, potrivit legii, starea de asediu sau starea de urgență, în întreaga țară ori în unele unități administrativ teritoriale și solicită Parlamentului încuviințarea măsurii adoptate, în cel mult cinci zile de la luarea acesteia. Instituirea stării de urgență sau de asediu se face prin decret prezidențial contrasemnat de primministru, conform art. 100 alin. 2 din Constituție. De asemenea, la art. 73 alin. 3 lit. g din Constituție se prevede că regimul stării de urgență și al stării de asediu se reglementează prin lege organică.

În România, regimul stării de asediu și al stării de urgență este reglementat de OUG nr. 1/1999 aprobată prin Legea nr. 453/2004 a Parlamentului României. În ordonanța de urgență se prevede în mod expres că decretul Președintelui României privind instituirea stării de urgență sau a stării de asediu trebuie să cuprindă măsurile de primă urgență care trebuie luate în astfel de situații, respectiv drepturile și libertățile fundamentale al căror exercițiu se restrânge, în limitele prevederilor constituționale și ale ordonanței de urgență.

Raportat la dispozițiile constituționale și legale de mai sus, ne putem întreba ce înseamnă că Președintele instituie, potrivit legii, starea de asediu sau de urgență? Care este semnificația constituțională a sintagmei „instituie, potrivit legii"? Se referă la faptul că Președintele are doar competența de a declara starea de urgență sau starea de asediu, sub controlul ulterior al unui Parlament care se bucură doar de competența de încuviințare a măsurii? Sau se referă la faptul 
Lect. univ. dr. Bogdan Dima

Facultatea de Drept, Universitatea din București

Președinte Asociația Centrul pentru Analize Strategice

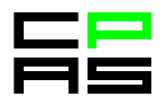

că Președintele are competența de a pune în aplicare/de a executa dispozițiile legii care stabilește regimul juridic al stării de asediu sau al stării de urgență în România?

Din punctul meu de vedere, într-o interpretare textualistă, sintagma „instituie, potrivit legii” nu poate fi înțeleasă ca o simplă declarație formală din partea Președintelui a stării de urgență sau a stării de asediu. Dacă aceasta ar fi fost semnificația urmărită de legiuitorul constituant, precizarea expresă „potrivit legii” nu și-ar mai fi avut rostul.

Însă, tocmai pentru că legiuitorul constituant trimite expres la o lege care stabilește regimul juridic al stării de urgență și al stării de asediu, semnificația verbului „a institui” implică ceva mai mult decât o declarare formală a respectivelor stări. Astfel, atunci când se instituie o ordine juridică specială, conform legii, aceasta se instituie în totalitatea sa. Instituirea nu se poate rezuma doar la declararea formală. Stabilește inclusiv procedura de instituire și măsurile pentru implementarea ordinii juridice speciale, măsuri care sunt prevăzute în mod expres tocmai de ordinea juridică instituită.

De altfel, să ne aducem aminte de art. 64 alin. 4 din Constituția României. În acest articol este utilizat verbul „a institui”. Astfel, se prevede, printre altele, că fiecare Cameră a Parlamentului poate institui comisii de anchetă sau alte comisii speciale. Vă puteți imagina cât de absurdă ar fi o interpretare conform căreia legiuitorul constituant a urmărit ca prin acest text constituțional să prevadă doar instituirea/declararea formală a existenței unei comisii de anchetă, fără să îi stabilească în concret competențele și procedura de lucru prin actul de instituire?

Așadar, cel puțin în opinia mea, atât timp cât legea organică a stabilit regimul juridic al stării de urgență și al stării de asediu, instituirea acestor stări prin decret prezidențial, potrivit legii, presupune instituirea întregului regim juridic aplicabil, iar nu o simplă și formală declarare a existenței stării de urgență sau a stării de asediu prin decret prezidențial.

Ca atare, dacă legiuitorul a considerat că Președintele României trebuie să stabilească măsurile de urgență care trebuie luate și să identifice drepturile și libertățile al căror exercițiu este restrâns în stare de urgență, atunci Președintele, când instituie starea de urgență sau când o prelungește, are obligația să respecte dispozițiile legale în materie. Cum le respectă, asta este o chestiune de apreciere pe care nu o poate face altcineva decât instanța de contencios administrativ, dacă este sesizată și, evident, dacă are curajul să își exercite competențele, garantând, astfel, chiar statul de drept.

\section{Competența de legiferare nu se confundă cu atribuțiile legale}

Analizând conținutul celor două decrete ale Președintelui României emise pentru instituirea, respectiv prelungirea stării de urgență, am observat că acestea cuprind o serie de măsuri care organizează executarea dispozițiilor OUG nr. 1/1999 și particularizează/adaptează respectivele dispoziții la anumite domenii de activitate esențiale pentru gestionarea crizei sanitare provocate de COVID-19 (sănătate, economie, justiție, educație, achiziții publice etc.).

Chiar și măsurile urgente cu aplicabilitate graduală din Anexa 2 a celor două decrete, care vizează restrângerea exercițiului unor drepturi și libertăți fundamentale ale cetățenilor, sunt măsuri de 
Lect. univ. dr. Bogdan Dima

Facultatea de Drept, Universitatea din București

Președinte Asociația Centrul pentru Analize Strategice

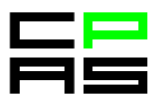

organizare a executării dispozițiilor art. 20 din OUG nr. 1/1999, întrucât particularizează/adaptează/identifică, prin raportare la situația de fapt existentă, care sunt drepturile și libertățile fundamentale al căror exercițiu se restrânge în temeiul legii. Altfel spus, nici decretele Președintelui, nici ordonanțele militare emise în temeiul OUG nr. 1/1999 nu reglementează cu titlu primar restrângerea exercițiului unor drepturi și libertăți fundamentale. Această restrângere $a$ fost deja reglementată la nivel primar prin actul normativ OUG nr. 1/1999 aprobat prin Legea nr. 453/2004.

Așadar, cum se poate considera că Președintele României reglementează primar restrângerea unor drepturi și libertăți prin decretul prezidențial când legea pe care o pune în aplicare raportat la situația de fapt a reglementat deja cu titlu general și temporar (doar pe perioada stării de urgență) restrângerea exercițiului unor drepturi și libertăți? Dacă sunt neclare sau imprecise dispozițiile OUG nr. 1/1999 prin care s-a reglementat restrângerea exercițiului unor drepturi sau libertăți fundamentale, dacă respectă sau nu condițiile prevăzute la art. 53 din Constituție sunt aspecte pe care le poate verifica doar Curtea Constituțională. Însă, într-un asemenea caz, trebuie înțeles și faptul că legislația care prevede regimul juridic al stării de excepție presupune în mod invariabil un grad de generalitate mai mare decât legislația aplicabilă în perioada de normalitate, tocmai pentru că particularitățile stării de excepție sunt excepționalitatea și imprevizibilitatea pericolului care afectează atât societatea în ansamblul său, cât și fiecare individ în parte. Nu este întâmplător faptul că însăși CEDO prevede în art. 15 posibilitatea adoptării de măsuri derogatorii de la Convenție în caz de război sau de alt pericol public ce ameninţă viaţa naţiunii.

Din aceste motive, din punctul meu de vedere, argumentul Avocatului Poporului utilizat în excepția de neconstituționalitate pe care a ridicat-o mai deunăzi cu privire la unele dispoziții din OUG nr. 1/1999 este eronat. Implică o confuzie uriașă între competența de legiferare a regimului stării de urgență și a stării de asediu, care aparține Parlamentului și atribuțiile legale ale Președintelui, care stabilesc conținutul unei competențe de rang administrativ, anume de punere în executare a dispozițiilor legale ale regimului stării de urgență sau de asediu. Cui nu îi convine acest lucru, poate să schimbe legea și să ofere altcuiva competența de organizare a executării regimului juridic al stării de urgență.

În concluzie, decretele Președintelui emise în temeiul art. 93 și al OUG nr. 1/1999 sunt acte administrative normative care stabilesc o competență de rang administrativ pentru șeful executivului, în sensul că organizează executarea prevederilor de rang legal din OUG nr. 1/1999 aprobată prin lege organică nr. 453/2004 de către Parlamentul României.

Desigur, așa cum am mai spus, tocmai pentru că este un act administrativ normativ, decretul Președintelui poate fi și el supus unui control de legalitate în fața instanței de contencios administrativ în temeiul art. 5 alin. 3 din Legea contenciosului administrativ. Instanța va putea verifica dacă Președintele a depășit competența stabilită de legiuitor și a acționat cu exces de putere, depășind scopul normei. Dacă este acceptat orice alt control cu privire la conținutul acestui decret, înseamnă că decretul nu mai are natura juridică a unui act administrativ normativ 
Lect. univ. dr. Bogdan Dima

Facultatea de Drept, Universitatea din București

Președinte Asociația Centrul pentru Analize Strategice

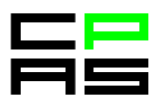

și devine altceva. Ce devine, nu ne pot spune decât cei care îl controlează, fiecare după judecata proprie.

\section{Dincolo de lege este întotdeauna capul de Gorgonă al politicul (de la Hans Kelsen citire)}

Toată această degringoladă constituțională, legală și administrativă care vine la pachet cu raporturile conflictuale dintre executiv și legislativ creează o agitație mare și inutilă în spațiul public. Însă, este o agitație justificată pentru cei care o fac pentru promovarea intereselor grupului politic pe care îl simpatizează.

Din perspectiva unui constituționalist, lucrurile nu par chiar atât de grave. Tărăboiul acesta constituțional arată că incipienta democrație constituțională autohtonă este încă vie, chiar dacă înceată la minte. Există, iată, un control politic reciproc între cele două puteri politice ale statului. Ca urmare a situației de coabitare în care ne aflăm, nu este posibilă (acum cel puțin) nici concentrarea întregii puteri de stat în mâinile executivului (ceea ce este foarte ușor în stare de excepție), nici concentrarea întregii puteri de stat în mâinile legislativului (ceea ce este foarte ineficient în stare de excepție). Prin „mișcarea necesară a lucrurilor” (le mouvement nécessaire des choses), cum zicea pe vremuri Montesquieu, grupurile politice sunt nevoite să negocieze și să ajungă la un compromis util pentru eliminarea pericolului care afectează viața membrilor colectivității. Din păcate, însă, pe tărâmurile românești nu am înțeles decât pe jumătate semnificația principiului separației puterilor în stat: separația prin conflict, nu și echilibrul prin negocierea compromisului util.

Din perspectiva unui cetățean, acțiunea autorităților statului în stare de urgență trebuie să fie unitară, coordonată și să exprime încredere. În mod normal într-o democrație consolidată, în astfel de situații excepționale, executivul decide, parlamentul controlează decizia executivului, iar autoritatea judecătorească veghează ca măsurile executivului să fie proporționale cu situația de fapt care le-a determinat. Dar, cum să faci acest lucru când, de fiecare dată, liderii politici își pun bețe în roate, deși niciunul n-a știut niciodată prea bine cum se merge pe bicicletă ...

Materialul a fost publicat pe G4media.ro și preluat ulterior în revista online a Facultății de Drept, AUBD - Forum juridic $\mathrm{nr} 1 / 2020$. 